\title{
Effect of Graphene Oxide on the Crystallization of Calcium Carbonate by $\mathrm{C}_{3} \mathrm{~S}$ Carbonation
}

\author{
Dapeng Zheng ${ }^{1,2}$, Haibin Yang ${ }^{1,2}$, Feng Yu ${ }^{1}$, Bo Zhang ${ }^{1}$ and Hongzhi Cui ${ }^{1, *}$ \\ College of Civil and Transportation Engineering, Shenzhen University, Shenzhen 518060, China \\ 2 Department of Architecture and Civil Engineering, City University of Hong Kong, Hong Kong, China \\ * Correspondence: h.z.cui@szu.edu.cn; Tel.: +86-755-26917849
}

Received: 16 May 2019; Accepted: 20 June 2019; Published: 26 June 2019

\begin{abstract}
The effect of graphene oxide (GO) on the crystallization of calcium carbonate $\left(\mathrm{CaCO}_{3}\right)$ is explored in this paper. Precipitation of $\mathrm{CaCO}_{3}$ was carried out by bubbling carbon dioxide $\left(\mathrm{CO}_{2}\right)$ through tricalcium silicate $\left(\mathrm{C}_{3} \mathrm{~S}\right)$ hydration solution with different graphene oxide admixture contents $\left(0.2 \%, 1 \%\right.$ and $2 \%$ mass ratios based on $\left.\mathrm{C}_{3} \mathrm{~S}\right)$. The polymorph, morphology, crystal size and particle size of $\mathrm{CaCO}_{3}$ were evaluated using X-ray diffraction (XRD), an environmental scanning electronic microscope (ESEM), and laser particle size analysis. The results showed that addition of GO was able to promote the conversion of $\mathrm{CaCO}_{3}$ to a calcite crystal phase with higher thermal stability and crystallinity than the control. However, as the dosage of GO increased, the growth of the calcite crystal particles was somewhat suppressed, resulting in a decrease in the crystal particle size and a narrow particle size distribution. When the amount of GO was $0.2 \%, 1 \%$ and $2 \%$, the crystal size of the calcite was $5.49 \%, 12.38 \%$, and $24.61 \%$ lower than that of the sample without GO, respectively, while the particle size of the calcite also decreased by $17.21 \%, 39.26 \%, 58.03 \%$, respectively.
\end{abstract}

Keywords: calcium carbonate; graphene oxide; carbonization; polymorph; crystal size

\section{Introduction}

In recent years, the application of graphene oxide (GO) has been widely studied because of its unique physicochemical and structural properties [1,2]. Some studies [3-8] have reported that $\mathrm{GO}$, as a reinforcing material, can improve the mechanical properties and microstructure of cementitious composites because of its high specific strength, high toughness, large specific surface area and low weight. Calcium carbonate $\left(\mathrm{CaCO}_{3}\right)$, as a common cementitious composite, may have its carbonation process enhanced by applying nanomaterials such as $\mathrm{GO} . \mathrm{CaCO}_{3}$ has been widely used in various industries, such as rubber, ink, plastics and building materials $[9,10]$. At present, various methods for preparing $\mathrm{CaCO}_{3}$ have been explored, such as carbonization, chemical precipitation [11], ultrasonic assisted synthesis [12], in situ deposition methods [13], and biologically controlled $\mathrm{CaCO}_{3}$ deposition [14,15]. Carbonization is an industrially useful method because it is environmentally friendly effectively uses mineral resources $[16,17]$. The crystallization, morphology, crystal size, and phase structure of $\mathrm{CaCO}_{3}$ are affected by admixture, temperature, concentration, and so on [18-22]. Currently, researchers usually use a variety of additives, such as surfactants, metallic ions, and GO, to control the crystallization, nucleation and crystal growth process of $\mathrm{CaCO}_{3}$ [23-28].

Carbonization is a very common phenomenon in the hydration process of cement. As the main product of the cement carbonization reaction, the formation of $\mathrm{CaCO}_{3}$ reduces the alkalinity of concrete and weakens the protection of steel bars [29]. On the other hand, the formation of $\mathrm{CaCO}_{3}$ can make concrete structures more compact and consequently improve their mechanical properties [30-34]. Besides, many studies have shown that calcium carbonates with different morphologies and crystalline structures have different effects on the microstructure of cement [34-36]. Due to the excellent mechanical 
properties of GO, the possibility of its application in cement has been extensively explored. Previous studies have reported that addition of GO promoted the hydration of cement and significantly increased the compressive and flexural strength of cement [37-39]. In a recent study, Lv et al. [40] found that the addition of GO was capable of affecting the shape of cement hydration products, such as ettringite (AFt) and monosulfate (AFm). However, Cui et al. [41] subsequently questioned this finding and experimentally confirmed that the change in shape of the hydration product was the result of a carbonization reaction. Nevertheless, in the carbonization process of cement, the effect of GO on the polymorph, morphology, and crystal size of $\mathrm{CaCO}_{3}$ has not been directly studied.

Whether as an additive material or a carbonized product of cement, the properties of $\mathrm{CaCO}_{3}$ can have a significant impact on the performance of cement. As the major mineral component in Portland cement, the hydration reaction of tricalcium silicate $\left(C_{3} S\right)$ largely represents the hydration process of cement. Therefore, this study only focused on $\mathrm{C}_{3} \mathrm{~S}$ hydration to simulate the hydration process of cement. Precipitation of $\mathrm{CaCO}_{3}$ was carried out by bubbling carbon dioxide $\left(\mathrm{CO}_{2}\right)$ through $\mathrm{C}_{3} \mathrm{~S}$ hydration solution with different GO admixture contents $(0.2 \%, 1 \%$ and $2 \%$ mass ratios based on $\mathrm{C}_{3} \mathrm{~S}$ ). The effects of GO on the polymorphism, morphology, crystal size and particle size of $\mathrm{CaCO}_{3}$ during cement carbonization were investigated by X-ray diffraction (XRD), an environmental scanning electronic microscope (ESEM), and laser particle size analysis.

\section{Materials and Methods}

\subsection{Materials}

The XRD pattern of the $C_{3} S$ used in this research is shown in Figure 1. According to the peak correspondence of PDF\#49-0442, it can be seen that the sample tested was $\mathrm{C}_{3} \mathrm{~S}$ crystal, and the sample was highly pure with almost no other crystal impurities. A GO dispersion $(6.4 \mathrm{~g} / \mathrm{L}$, Laboratory synthesis) was also used in this experiment, along with pure $\mathrm{CO}_{2}$ supplied by Shente company (Shenzhen, China) and distilled water.

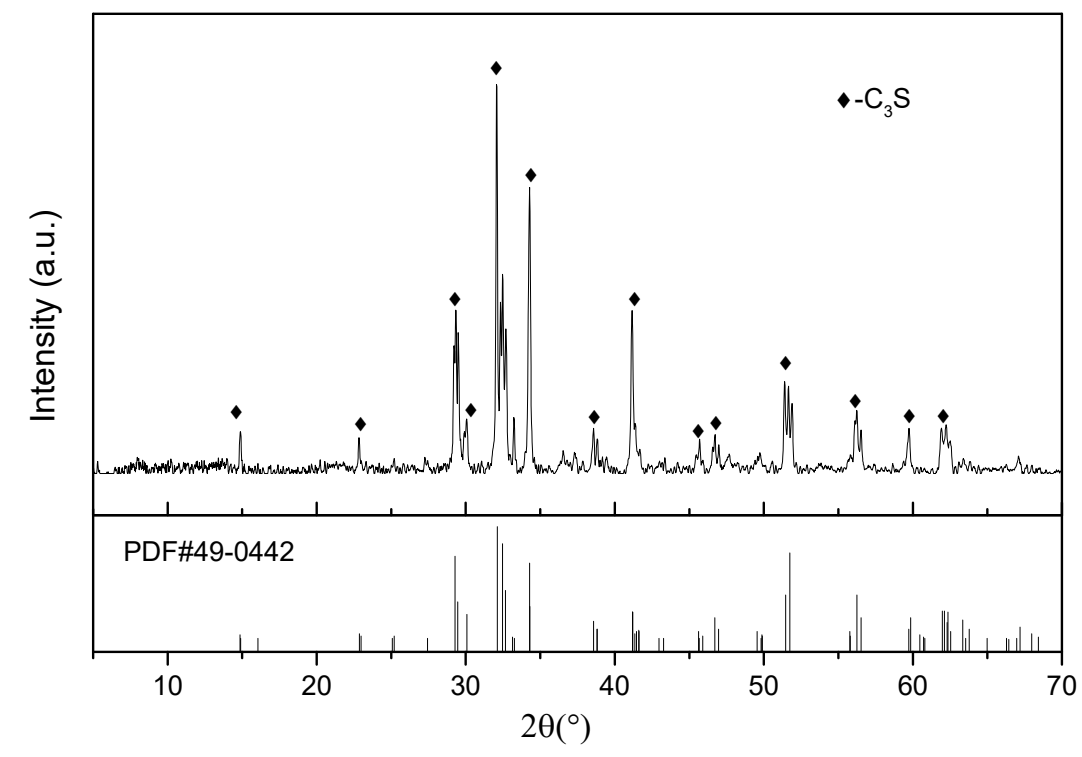

Figure 1. X-ray diffraction (XRD) patterns of tricalcium silicate $\left(C_{3} S\right)$.

\subsection{Synthesis of $\mathrm{CaCO}_{3}$ by the Carbonation Method}

Carbonation was used in this experiment to synthesize $\mathrm{CaCO}_{3}$ [42]. Firstly, $\mathrm{C}_{3} \mathrm{~S}$ was mixed with distilled water and different mass ratios of $\mathrm{GO}(0.2 \%, 1 \%$, and $2 \%)$ in a three-necked flask. The mass ratio of $C_{3} S$ to water was set to $1 / 140$. The mixture was stirred under sealed conditions for $24 \mathrm{~h}$ with a constant stirring rate of $300 \mathrm{rpm}$ [43]. After $24 \mathrm{~h}$ of the hydration reaction, pure $\mathrm{CO}_{2}$ was introduced into the slurry through a tube at a speed of $100 \mathrm{ml} / \mathrm{min}$. As the $\mathrm{pH}$ of the slurry decreased to 7 , 
the passage of $\mathrm{CO}_{2}$ was stopped. The resulting precipitate was separated from the mother liquor by suction filtration and washed with distilled water. Finally, the precipitate was dried in an oven at $80^{\circ} \mathrm{C}$ for $24 \mathrm{~h}$. The hydration reaction of $\mathrm{C}_{3} \mathrm{~S}$ produces calcium silicate hydrate (C-S-H) gel and the carbonation reaction can be represented by the following expressions [44]:

$$
\begin{gathered}
\mathrm{CO}_{2}+\mathrm{H}_{2} \mathrm{O} \leftrightarrow \mathrm{H}_{2} \mathrm{CO}_{3} \leftrightarrow \mathrm{H}^{+}+\mathrm{HCO}_{3}{ }^{-} \leftrightarrow 2 \mathrm{H}^{+}+\mathrm{CO}_{3}{ }^{2-} \\
\mathrm{C}_{3} \mathrm{~S}+6 \mathrm{H}_{2} \mathrm{O} \rightarrow \mathrm{C}-\mathrm{S}-\mathrm{H}+3 \mathrm{Ca}(\mathrm{OH})_{2} \\
\mathrm{Ca}(\mathrm{OH})_{2}+2 \mathrm{H}^{+}+\mathrm{CO}_{3}{ }^{2-} \rightarrow \mathrm{CaCO}_{3}+2 \mathrm{H}_{2} \mathrm{O} \\
\mathrm{C}-\mathrm{S}-\mathrm{H}+2 \mathrm{H}^{+}+\mathrm{CO}_{3}{ }^{2-} \rightarrow \mathrm{CaCO}_{3}+\mathrm{SiO}_{\mathrm{x}} \mathrm{OH}_{\mathrm{x}} \\
\mathrm{C}-\mathrm{S}-\mathrm{H}+\mathrm{H}^{+}+\mathrm{HCO}_{3}{ }^{-} \rightarrow \mathrm{CaCO}_{3}+\mathrm{SiO}_{\mathrm{x}} \mathrm{OH}_{\mathrm{x}}
\end{gathered}
$$

\subsection{Characterization Methods}

The morphology of the final $\mathrm{CaCO}_{3}$ products was observed using an environmental scanning electronic microscope (ESEM, Quanta TM 250 FEG, 20 KV, Hillsboro, OR, USA). The sample surface was coated with a thin layer of gold nanoparticles prior to ESEM testing. X-ray diffraction (XRD, D8 Advance, Bruker, Karlsruhe, Germany) was used to analyze the polymorph of the samples at a scanning rate of $2^{\circ} / \mathrm{min}$ from $10^{\circ}$ to $70^{\circ}$ with $\mathrm{Cu} \mathrm{K} \alpha$ radiation $(\lambda=1.5405 \AA)$ on a $\mathrm{D}$ max/RB diffractometer. The particle size distribution of the $\mathrm{CaCO}_{3}$ was measured by wide-angle, static-dynamic, synchronous laser scattering (Mastersizer 2000, Malvern, UK). All tests were carried out at room temperature.

\section{Results and Discussion}

\subsection{Effect of $\mathrm{GO}$ on the Crystal Polymorph of $\mathrm{CaCO}_{3}$}

The $\mathrm{CaCO}_{3}$ crystals formed by carbonization of the $\mathrm{C}_{3} \mathrm{~S}$ hydration products-with different mass ratios of GO-were measured by XRD. As shown in Figure 2, diffraction peaks of $2 \theta$ at $23.06^{\circ}, 29.41^{\circ}$, $35.96^{\circ}, 39.42^{\circ}$, and $43.17^{\circ}$ corresponded with (012), (104), (110), (113), and (202) crystallographic planes of calcite, respectively, while peaks at $24.87^{\circ}, 27.18^{\circ}$ and $32.71^{\circ}$ corresponded with (100), (101), and (102) crystallographic planes of vaterite [1]. In Figure 2, it can also be observed that the $\mathrm{CaCO}_{3}$ formed via the carbonization reaction without GO contained two crystals of calcite and vaterite. When GO was present, regardless of the amount, all of the $\mathrm{CaCO}_{3}$-obtained via the reaction of the $\mathrm{C}_{3} \mathrm{~S}$ hydration product with $\mathrm{CO}_{2}$-was converted into calcite. Previous studies have shown that $\mathrm{CaCO}_{3}$ exhibits three polymorphic forms, namely calcite, aragonite and vaterite $[45,46]$. Among them, calcite is the most stable form in thermodynamics, while vaterite is the most unstable [47]. Combined with the XRD results, we can conclude that the addition of GO was able to promote the formation of calcite during the carbonation of the $\mathrm{C}_{3} \mathrm{~S}$ hydration products. Yao et al. gave a similar conclusion when they used $\mathrm{CaCl}_{2}$ and $\left(\mathrm{NH}_{4}\right)_{2} \mathrm{CO}_{3}$ (as sources of calcium) in conjunction with $\mathrm{CO}_{2}$ to prepare $\mathrm{CaCO}_{3}$ via a precipitation reaction [1]. Some researchers $[1,28]$ believe that $-\mathrm{COOH}$ on the surface of $\mathrm{GO}$ can coordinate with $\mathrm{Ca}^{2+}$ ions in solution to provide a nucleation site for crystallization of $\mathrm{CaCO}_{3}$, thereby promoting crystallization of $\mathrm{CaCO}_{3}$. However, the present study shows an interesting phenomenon-that $\mathrm{GO}$ can still affect the crystallization of $\mathrm{CaCO}_{3}$ after participating in the $\mathrm{C}_{3} \mathrm{~S}$ hydration for $24 \mathrm{~h}$, indicating that the cement modified by GO is still likely to be affected by the presence of GO during carbonization. This phenomenon may be due to the linkage of GO to C-S-H [48], which affects the subsequent carbonization process. 


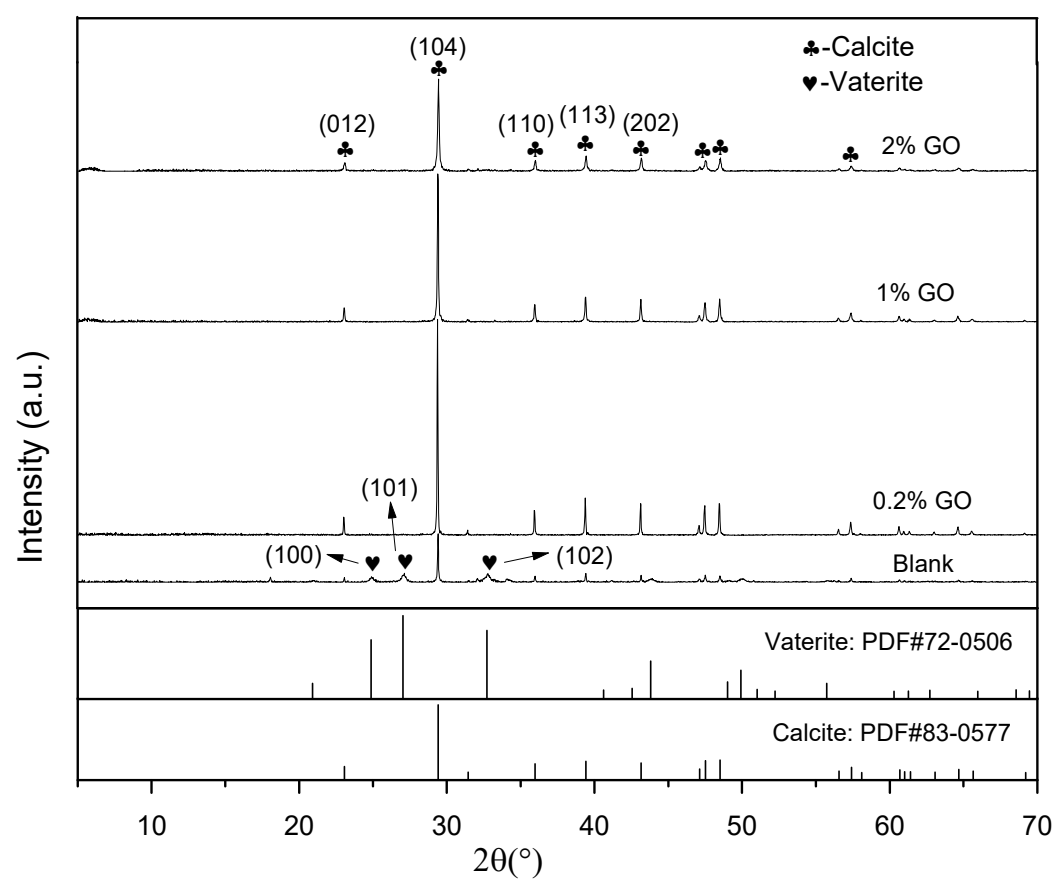

Figure 2. XRD patterns of calcium carbonate $\left(\mathrm{CaCO}_{3}\right)$ crystals prepared with different content of graphene oxide $(\mathrm{GO})$.

\subsection{Effect of $\mathrm{GO}$ on the Crystal Size of $\mathrm{CaCO}_{3}$}

The Debye-Scherrer equation, as expressed in Equation (6), was used to analyze the crystal size of the samples [3].

$$
\mathrm{D}=\frac{\mathrm{K} \lambda}{\beta \cos \theta}
$$

where: $\mathrm{D}$ is the size of grains in the direction perpendicular to the crystal plane; $\mathrm{K}$ is a constant ( $K=0.89$ when the particles are spherical or $K=0.943$ when the particles are cubic); $\lambda$ is the $X$-ray wavelength; $\beta$ stands for the diffraction peak half-width when the particles are spherical, while $\beta$ should be converted to radians, represented by $\beta^{\prime}$, when the particles are cubic (Equation (7)); and $\theta$ is the diffraction angle of the $\mathrm{X}$-ray.

$$
\beta^{\prime}=(\beta \times \pi) / 180
$$

Table 1 shows the effect of GO dosage on the diffraction angle, peak height and crystal size of the calcite formed by the carbonation of $\mathrm{C}_{3} \mathrm{~S}$ hydration products. As shown in Table 1 , the diffraction angle of the calcite remained almost the same regardless of the GO content. This indicated that the addition of GO had no effect on the unit cell parameters of the calcite. The diffraction peak height of the (104) plane for the blank sample was 1860, and the corresponding crystal size of the calcite was $90.63 \mathrm{~nm}$. However, compared with the blank sample, the diffraction peak intensity of the (104) plane for the calcite increased by $346.34 \%, 206.18 \%$, and $90.38 \%$, while the size of the calcite crystals decreased by $5.49 \%, 12.38 \%$, and $24.61 \%$ when the amount of GO was set to $0.2 \%, 1 \%$, and $2 \%$, respectively. The peak height and crystal size of the calcite at (012), (110), (113) and (202) planes showed the same changes in regularity. A comparison of the diffraction peak heights and crystal sizes of each group showed that the addition of GO increased the peak height of the calcite while decreasing its crystal size. At the same time, with the increase of GO content, both the peak height and crystal size gradually decreased. Combined with the results of Figure 1, it can be concluded that the presence of GO promoted the conversion of $\mathrm{CaCO}_{3}$ to the most stable calcite crystal phase with high crystallinity. However, when the GO dosage was increased, the growth of the calcite crystal particles was somewhat suppressed, and thus the crystal grain size gradually reduced. 
Table 1. The diffraction angle, peak height and crystal size of the calcite prepared with different content of GO.

\begin{tabular}{|c|c|c|c|c|}
\hline h, $k, 1$ & GO $\%$ & $2 \theta\left(^{\circ}\right)$ & Peak Height & Crystal Size (nm) \\
\hline \multirow{4}{*}{012} & 0 & 23.031 & 178 & 92.38 \\
\hline & 0.2 & 23.053 & 697 & 87.62 \\
\hline & 1 & 23.055 & 549 & 81.72 \\
\hline & 2 & 23.055 & 225 & 60.71 \\
\hline \multirow{4}{*}{104} & 0 & 29.369 & 1860 & 90.63 \\
\hline & 0.2 & 29.399 & 8302 & 85.65 \\
\hline & 1 & 29.400 & 5695 & 79.41 \\
\hline & 2 & 29.400 & 3541 & 68.33 \\
\hline \multirow{4}{*}{110} & 0 & 35.936 & 227 & 84.43 \\
\hline & 0.2 & 35.968 & 954 & 79.34 \\
\hline & 1 & 35.973 & 674 & 74.83 \\
\hline & 2 & 35.973 & 417 & 67.35 \\
\hline \multirow{4}{*}{113} & 0 & 39.369 & 332 & 93.11 \\
\hline & 0.2 & 39.408 & 1441 & 83.44 \\
\hline & 1 & 39.411 & 964 & 80.41 \\
\hline & 2 & 39.411 & 588 & 59.37 \\
\hline \multirow{4}{*}{202} & 0 & 43.116 & 265 & 93.28 \\
\hline & 0.2 & 43.157 & 1221 & 89.72 \\
\hline & 1 & 43.162 & 875 & 81.41 \\
\hline & 2 & 43.162 & 501 & 60.11 \\
\hline
\end{tabular}

The particle size distribution of the $\mathrm{CaCO}_{3}$ prepared with different mass ratios of $\mathrm{GO}$ were measured using a laser particle size analyzer. The differential and integral curves of the particle size distribution are shown in Figure 3. From this figure, it is obvious that both the differential and integral curves shifted to the left after the addition of GO, and that the shift amplitude increased with increasing $\mathrm{GO}$ dosage, indicating that the particle size of the $\mathrm{CaCO}_{3}$ particles formed by the carbonization reaction became smaller.

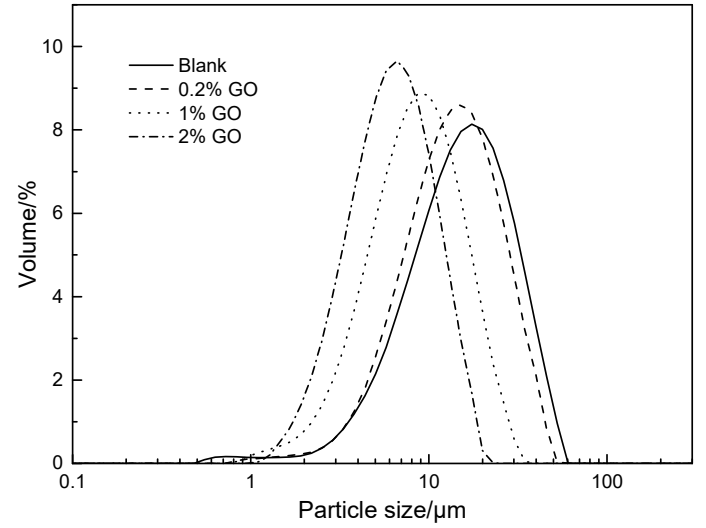

(a)

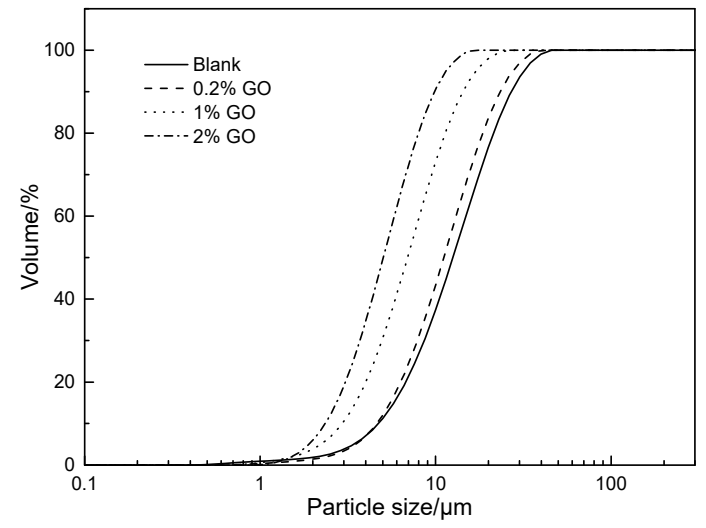

(b)

Figure 3. Particle size distribution of $\mathrm{CaCO}_{3}$ prepared with different dosages of GO: (a) Differential distribution, and (b) integral distribution.

These results were then evaluated by the Rosin-Rammler distribution function, which is commonly used to simulate and analyze the particle size distribution of powders, such as dust and limestone [49]. The Rosin-Rammler distribution function is shown in Equation (8).

$$
R(D p)=1-\exp \left[-\left(D_{p} / D_{e}\right)^{n}\right]
$$


where: $D_{p}$ is the corresponding particle diameter $(\mu \mathrm{m}) ; R\left(D_{p}\right)$ is the cumulative percentage over size $(\%)$; De is a constant-related particle size; and the index, $\mathrm{n}$, is a constant, which is related to the range of the particle size distribution. The larger the value of $n$, the narrower the distribution range of the particle diameter. The fitting results of the $\mathrm{CaCO}_{3}$ particle size distribution by the Rosin-Rammler function are displayed in Table 2.

Table 2. Fitting results of $\mathrm{CaCO}_{3}$ particle size distribution.

\begin{tabular}{ccc}
\hline GO $\%$ & n Value & De Value $(\boldsymbol{\mu m})$ \\
\hline 0 & 1.847 & 15.705 \\
0.2 & 1.999 & 13.002 \\
1 & 2.159 & 9.540 \\
2 & 2.256 & 6.591 \\
\hline
\end{tabular}

As seen in Table 2, the $\mathrm{n}$ value of the $\mathrm{CaCO}_{3}$ particles formed when no $\mathrm{GO}$ was added in the preparation process was 1.847, with an average particle size of $15.705 \mu \mathrm{m}$. Interestingly, we found that the $n$ value increased while De decreased with increasing GO dosage. When the amount of GO was gradually increased from $0.2 \%$ to $2 \%$, the value of $n$ continuously increased, whereas the value of De decreased significantly $(17.21 \%, 39.26 \%$, and $58.03 \%$ for $0.2 \%, 1 \%$, and $2 \%$ GO content, respectively). This means that the particle size of $\mathrm{CaCO}_{3}$ gradually became smaller and the particle size distribution became more uniform with increasing GO content. It has previously been reported that the size of $\mathrm{CaCO}_{3}$ particles is highly dependent on both the nucleation rate and the crystal growth rate, and that groups on the surface of GO-such as the carboxyl groups-may provide nucleation sites for $\mathrm{CaCO}_{3}$ and thereby promote the formation of calcite $[28,50]$. The observed narrowing of the particle size distribution and the large reduction in particle size appears to support the notion that the addition of $\mathrm{GO}$ promotes the nucleation rate of $\mathrm{CaCO}_{3}$ while reducing its growth rate. These results are also consistent with the findings presented in Figure 2 and Table 1 . However, it is worth considering that the carboxyl group on the surface of the GO-after participating in the hydration reaction-should have already captured the $\mathrm{Ca}^{2+}$. Therefore, it is unlikely to continue to be a nucleation site for $\mathrm{CaCO}_{3}$ crystallization during the carbonization process. There may be other mechanisms for the occurrence of this phenomenon, which requires further experimentation and analysis.

\subsection{Effect of $\mathrm{GO}$ on the Morphology of $\mathrm{CaCO}_{3}$}

Figure 4 presents ESEM images of the $\mathrm{CaCO}_{3}$ prepared with different contents of $\mathrm{GO}$. As depicted in Figure $4 \mathrm{a}$, the $\mathrm{CaCO}_{3}$ crystals were found to be cubic and spherical in shape when no GO was added into the mixture. According to the XRD results in Figure 2, the cubic-shaped particles are considered to be calcite while the spherical-shaped particles are vaterite. As shown in Figure $4 \mathrm{~b}-\mathrm{d}$, after the addition of $\mathrm{GO}$, the $\mathrm{CaCO}_{3}$ generated via carbonation were all square-shaped calcites. From these results, it can be concluded that the addition of $\mathrm{GO}$ created cubic-shaped $\mathrm{CaCO}_{3}$, and that changes in $\mathrm{GO}$ content did not affect the shape of the $\mathrm{CaCO}_{3}$. This is consistent with the findings shown in Figure 2. 


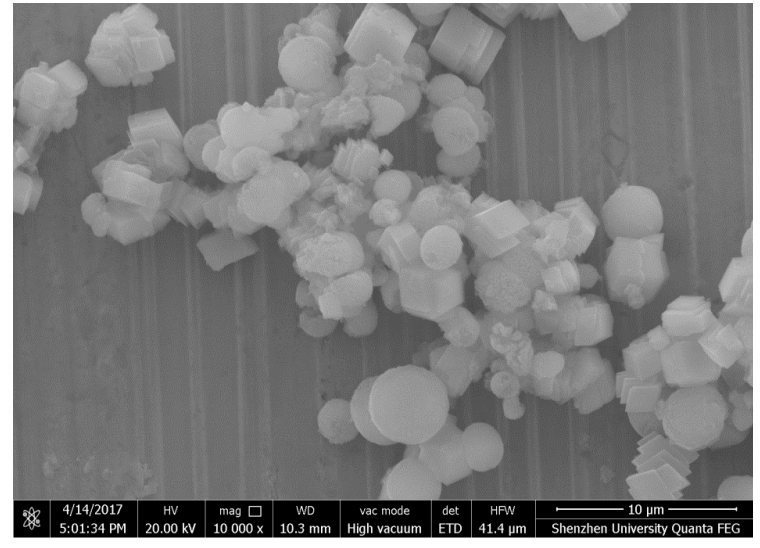

(a)

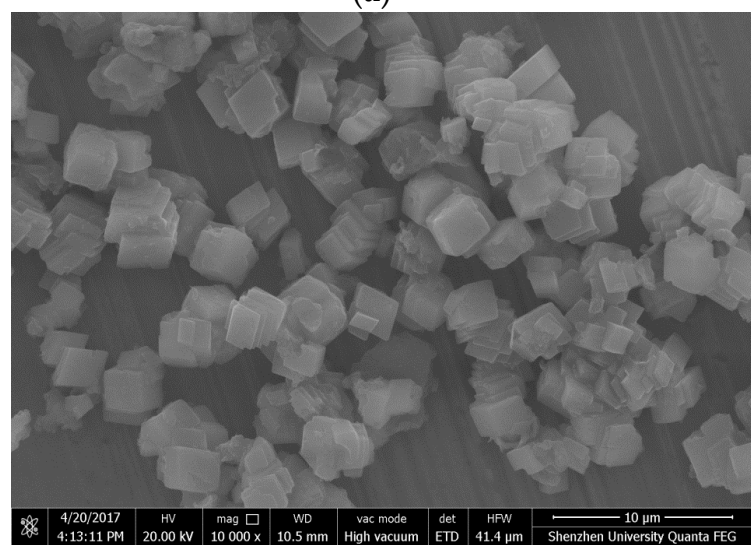

(c)

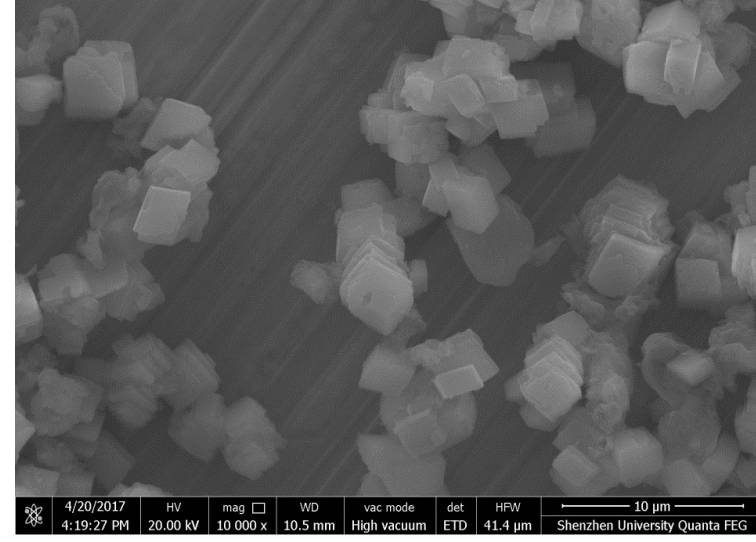

(b)

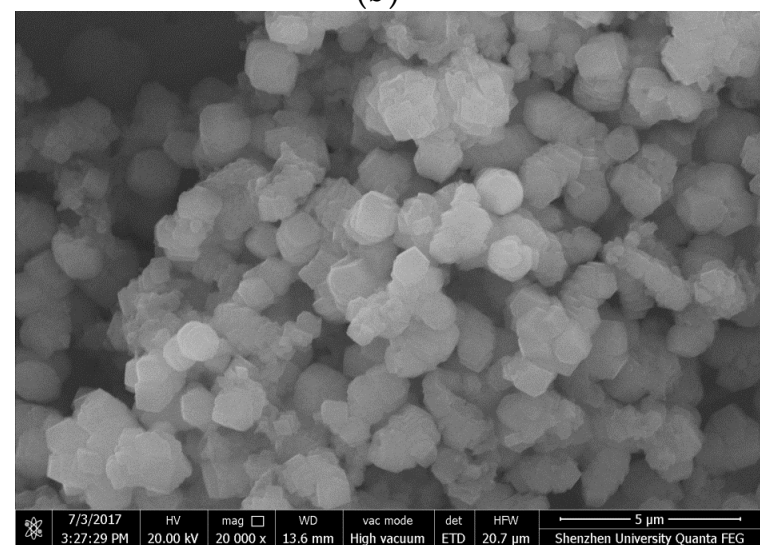

(d)

Figure 4. Environmental scanning electronic microscope (ESEM) images of $\mathrm{CaCO}_{3}$ crystals prepared with different mass ratios of GO: (a) No GO, (b) $0.2 \% \mathrm{GO}$, (c) $1 \% \mathrm{GO}$, and (d) $2 \% \mathrm{GO}$.

\section{Conclusions and Recommendations}

The effect of GO on the crystal phase and crystal size of $\mathrm{CaCO}_{3}$ during the carbonation of $\mathrm{C}_{3} \mathrm{~S}$ hydration products was investigated. From the results of XRD and SEM analysis, we concluded that the presence of $\mathrm{GO}$ promoted the conversion of $\mathrm{CaCO}_{3}$ to a crystal phase with higher thermal stability than the control-i.e., to a calcite crystal phase. However, an increase in the amount of GO had a certain inhibitory effect on the growth of the calcite crystal particles. From the test results, the crystal size of calcite became the largest when the lowest amount of GO was added. After participating in $\mathrm{C}_{3} \mathrm{~S}$ hydration for $24 \mathrm{~h}$, GO still had an effect on the polymorphism and crystal size of $\mathrm{CaCO}_{3}$, but the mechanism remains uncertain and further studies are needed. Although the polymorphism and crystal size of $\mathrm{CaCO}_{3}$ are discussed, the mechanical properties—such as elastic modulus and hardness value-have not been fully studied, and thus will become the focus of future research.

Author Contributions: H.C. and D.Z. conceived and designed the experiments; H.Y. and F.Y. performed the experiments; B.Z. and D.Z. analyzed the data; F.Y. contributed reagents/materials/analysis tools; D.Z. wrote the paper.

Funding: The work described in this paper was fully supported by grants from Natural Science Foundation of China (51678367).

Conflicts of Interest: The authors declare no conflict of interest. 


\section{Abbreviations}

$\begin{array}{ll}\mathrm{GO} & \text { Graphene oxide } \\ \mathrm{CaCO}_{3} & \text { Calcium carbonate } \\ \mathrm{C}_{3} \mathrm{~S} & \text { Tricalcium silicate }\left(3 \mathrm{CaO} \cdot \mathrm{SiO}_{2}\right) \\ \mathrm{C}-\mathrm{S}-\mathrm{H} & \text { Calcium silicate hydrate }\left(3 \mathrm{CaO} \cdot \mathrm{SiO}_{2} 3 \mathrm{H}_{2} \mathrm{O}\right) \\ \mathrm{CO}_{2} & \text { Carbon dioxide } \\ \mathrm{ESEM} & \text { Environmental scanning electronic microscope } \\ \mathrm{XRD} & \text { X-ray diffraction } \\ \mathrm{CaCl} & \text { Anhydrous calcium chloride } \\ \mathrm{AFt} & \text { Ettringite } \\ \mathrm{AFm} & \text { Monosulfate }\end{array}$

\section{References}

1. Yao, C.; Xie, A.; Shen, Y.; Zhu, J.; Li, H. Nacre-like calcium carbonate controlled by ionic liquid/graphene oxide composite template. Mater. Sci. Eng. C 2015, 51, 274-278. [CrossRef] [PubMed]

2. Cheng, Q.; Jiang, L.; Tang, Z. Bioinspired layered materials with superior mechanical performance. Acc. Chem. Res. 2014, 47, 1256-1266. [CrossRef] [PubMed]

3. Lin, C.; Wei, W.; Hu, Y.H. Catalytic behavior of graphene oxide for cement hydration process. J. Phys. Chem. Solids 2016, 89, 128-133. [CrossRef]

4. Tong, T.; Fan, Z.; Liu, Q.; Wang, S.; Tan, S.; Yu, Q. Investigation of the effects of graphene and graphene oxide nanoplatelets on the micro- and macro-properties of cementitious materials. Constr. Build. Mater. 2016, 106, 102-114. [CrossRef]

5. Wille, K.; Naaman, A.E.; El-Tawil, S.; Parra-Montesinos, G.J. Ultra-high performance concrete and fiber reinforced concrete: Achieving strength and ductility without heat curing. Mater. Struct. 2011, 45, 309-324. [CrossRef]

6. Zhu, Y.; Murali, S.; Cai, W.; Li, X.; Suk, J.W.; Potts, J.R.; Ruoff, R.S. Graphene and graphene oxide: Synthesis, properties, and applications. Adv. Mater. 2010, 22, 3906-3924. [CrossRef]

7. Yang, H.; Monasterio, M.; Cui, H.; Han, N. Experimental study of the effects of graphene oxide on microstructure and properties of cement paste composite. Compos. Part A Appl. Sci. Manuf. 2017, 102, 263-272. [CrossRef]

8. Yang, H.; Cui, H.; Tang, W.; Li, Z.; Han, N.; Xing, F. A critical review on research progress of graphene/cement based composites. Compos. Part A Appl. Sci. Manuf. 2017, 102, 273-296. [CrossRef]

9. Yu, J.; Lei, M.; Cheng, B.; Zhao, X. Facile preparation of calcium carbonate particles with unusual morphologies by precipitation reaction. J. Cryst. Growth 2004, 261, 566-570. [CrossRef]

10. Dalas, E.; Klepetsanis, P.; Koutsoukos, P. The overgrowth of calcium carbonate on poly (vinyl chloride-co-vinyl acetate-co-maleic acid). Langmuir ACS J. Surf. Colloids 1999, 15, 8322-8327. [CrossRef]

11. Kitamura, M.; Konno, H.; Yasui, A.; Masuoka, H. Controlling factors and mechanism of reactive crystallization of calcium carbonate polymorphs from calcium hydroxide suspensions. J. Cryst. Growth 2002, 236, 323-332. [CrossRef]

12. He, M.; Forssberg, E.; Wang, Y.; Han, Y. Ultrasonication-Assisted Synthesis of Calcium Carbonate Nanoparticles. Chem. Eng. Commun. 2005, 192, 1468-1481. [CrossRef]

13. Mishra, S.; Sonawane, S.H.; Singh, R.P. Studies on characterization of nano $\mathrm{CaCO}_{3}$ prepared by thein situ deposition technique and its application in PP-nano $\mathrm{CaCO}_{3}$ composites. J. Polym. Sci. Part B Polym. Phys. 2005, 43, 107-113. [CrossRef]

14. Nitta, I.; Kida, A.; Fujibayashi, Y.; Katayama, H.; Sugimura, Y. Calcium carbonate deposition in a cell wall sac formed in mulberry idioblasts. Protoplasma 2006, 228, 201-208. [CrossRef]

15. Robbins, L.; Blackwelder, P. Biochemical and ultrastructural evidence for the origin of whitings: A biologically induced calcium carbonate precipitation mechanism. Geology 1992, 20, 464-468. [CrossRef]

16. Wang, C.; Xiao, P.; Zhao, J.; Zhao, X.; Liu, Y.; Wang, Z. Biomimetic synthesis of hydrophobic calcium carbonate nanoparticles via a carbonation route. Powder Technol. 2006, 170, 31-35. [CrossRef]

17. Chen, Y.; Ji, X.; Zhao, G.; Wang, X. Facile preparation of cubic calcium carbonate nanoparticles with hydrophobic properties via a carbonation route. Powder Technol. 2010, 200, 144-148. [CrossRef] 
18. Dalas, E.; Malkaj, P. Calcium Carbonate Crystallization in the Presence of Aspartic Acid. Cryst. Growth Des. 2004, 4, 721-723.

19. Hashim, A.; Al-Hosney, V.H.G. Carbonic Acid an Important Intermediate in the Surface Chemistry of Calcium Carbonate. J. Am. Chem. Soc. 2004, 126, 8068-8069.

20. Chen, A.; Ma, P.; Fu, Z.; Wu, Y.; Kong, W. Crystallization and assembling behavior of calcium carbonate controlled by Ca-organic fibers. J. Cryst. Growth 2013, 377, 136-142. [CrossRef]

21. Guo, H.; Qin, Z.; Qian, P.; Yu, P.; Cui, S.; Wang, W. Crystallization of aragonite CaCO3 with complex structures. Adv. Powder Technol. 2011, 22, 777-783. [CrossRef]

22. Nassar, M.M.; Farrag, T.E.; Mahmoud, M.S.; Abdelmonem, S.; Khalil, K.A.; Barakat, N.A.M. Influence of the operating conditions on the morphology of $\mathrm{CaCO}_{3}$ nanoparticles prepared by modified co-precipitation with pulse mode feeding. Adv. Powder Technol. 2015, 26, 914-919. [CrossRef]

23. Xu, A.-W.; Dong, W.-F.; Antonietti, M.; Cölfen, H. Polymorph Switching of Calcium Carbonate Crystals by Polymer-Controlled Crystallization. Adv. Funct. Mater. 2008, 18, 1307-1313. [CrossRef]

24. Ji, X.; Li, G.; Huang, X. The synthesis of hollow CaCO3 microspheres in mixed solutions of surfactant and polymer. Mater. Lett. 2008, 62, 751-754. [CrossRef]

25. Nishino, Y.; Oaki, Y.; Imai, H. Magnesium-Mediated Nanocrystalline Mosaics of Calcite. Cryst. Growth Des. 2009, 9, 223-226. [CrossRef]

26. Cui, J.; Kennedy, J.F.; Nie, J.; Ma, G. Co-effects of amines molecules and chitosan films on in vitro calcium carbonate mineralization. Carbohydr. Polyme. 2015, 133, 67-73. [CrossRef] [PubMed]

27. Yuan, G.; Chen, X.; Li, X.; Liang, Q.; Miao, G.; Yuan, B. The synthesis of calcium carbonate microparticles with multiple morphologies through self-assembly method. Powder Technol. 2015, 284, 253-256. [CrossRef]

28. Yaseen, S.A.; Yiseen, G.A.; Li, Z. Synthesis of calcium carbonate in alkali solution based on graphene oxide and reduced graphene oxide. J. Sol. State Chem. 2018, 262, 127-134. [CrossRef]

29. Sun, J.; Lu, L. Coupled effect of axially distributed load and carbonization on permeability of concrete. Constr. Build. Mater. 2015, 79, 9-13. [CrossRef]

30. Wu, B.; Ye, G. Development of porosity of cement paste blended with supplementary cementitious materials after carbonation. Constr. Build. Mater. 2017, 145, 52-61. [CrossRef]

31. Zhang, D.; Shao, Y. Effect of early carbonation curing on chloride penetration and weathering carbonation in concrete. Constr. Build. Mater. 2016, 123, 516-526. [CrossRef]

32. Zelić, J.; Krstulović, R.; Tkalčec, E.; Krolo, P. Durability of the hydrated limestone-silica fume Portland cement mortars under sulphate attack. Cement Concr. Res. 1999, 29, 819-826. [CrossRef]

33. Vuk, T.; Tinta, V.; Gabrovšek, R.; Kaučič, V. The effects of limestone addition, clinker type and fineness on properties of Portland cement. Cement Concr. Res. 2001, 31, 135-139. [CrossRef]

34. Cao, M.; Ming, X.; He, K.; Li, L.; Shen, S. Effect of Macro-, Micro- and Nano-Calcium Carbonate on Properties of Cementitious Composites-A Review. Materials 2019, 12, 781. [CrossRef] [PubMed]

35. Ruan, S.; Unluer, C. Unluer, Influence of mix design on the carbonation, mechanical properties and microstructure of reactive $\mathrm{MgO}$ cement-based concrete. Cem. Concr. Compos. 2017, 80, 104-114. [CrossRef]

36. Jeong, Y.; Hargis, C.W.; Chun, S.; Moon, J. Effect of Calcium Carbonate Fineness on Calcium Sulfoaluminate-Belite Cement. Materials 2017, 10, 900. [CrossRef] [PubMed]

37. Kudzma, A.; Skamat, J.; Stonys, R.; Krasnikovs, A.; Kuznetsov, D.; Girskas, G.; Antonovic, V. Study on the Effect of Graphene Oxide with Low Oxygen Content on Portland Cement Based Composites. Materials 2019, 12, 802. [CrossRef] [PubMed]

38. Pan, Z.; He, L.; Qiu, L.; Korayem, A.H.; Li, G.; Zhu, J.W.; Collins, F.; Li, D.; Duan, W.H.; Wang, M.C. Mechanical properties and microstructure of a graphene oxide-cement composite. Cement Concr. Compos. 2015, 58, 140-147. [CrossRef]

39. Krystek, M.; Pakulski, D.; Patroniak, V.; Gorski, M.; Szojda, L.; Ciesielski, A.; Samori, P. High-Performance Graphene-Based Cementitious Composites. Adv. Sci. 2019, 6, 1801195. [CrossRef] [PubMed]

40. Lv, S.H.; Deng, L.J.; Yang, W.Q.; Zhou, Q.F.; Cui, Y.Y. Fabrication of polycarboxylate/graphene oxide nanosheet composites by copolymerization for reinforcing and toughening cement composites. Cement Concr. Compos. 2016, 66, 1-9. [CrossRef] 
41. Cui, H.; Yan, X.; Tang, L.; Xing, F. Possible pitfall in sample preparation for SEM analysis-A discussion of the paper "Fabrication of polycarboxylate/graphene oxide nanosheet composites by copolymerization for reinforcing and toughening cement composites" by Lv et al. Cement Concr. Compos. 2017, 77, 81-85. [CrossRef]

42. Sheng, Y.; Zhou, B.; Zhao, J.; Tao, N.; Yu, K.; Tian, Y.; Wang, Z. Influence of octadecyl dihydrogen phosphate on the formation of active super-fine calcium carbonate. J. Colloid Interface Sci. 2004, 272, 326-329. [CrossRef] [PubMed]

43. Monasterio, M.; Gaitero, J.J.; Erkizia, E.; Guerrero Bustos, A.M.; Miccio, L.A.; Dolado, J.S.; Cerveny, S. Effect of addition of silica- and amine functionalized silica-nanoparticles on the microstructure of calcium silicate hydrate (C-S-H) gel. J. Colloid Interface Sci. 2015, 450, 109-118. [CrossRef] [PubMed]

44. de Sena Costaa, B.L.; de Oliveira Freitas, J.C.; Santos, P.H.S.; de Araújo Melo, D.M.; de Oliveira, Y.H. Effects of carbon dioxide in Portland cement: A relation between static sedimentation and carbonation. Constr. Build. Mater. 2017, 150, 450-458. [CrossRef]

45. Kojima, Y.; Yamaguchi, K.; Nishimiya, N. Effect of amplitude and frequency of ultrasonic irradiation on morphological characteristics control of calcium carbonate. Ultrason. Sonochem. 2010, 17, 617-620. [CrossRef] [PubMed]

46. Kirboga, S.; Oner, M.; Akyol, E. The effect of ultrasonication on calcium carbonate crystallization in the presence of biopolymer. J. Cryst. Growth 2014, 401, 266-270. [CrossRef]

47. Kato, T.; Sugawara, A.; Hosoda, N. Calcium carbonate-organic hybrid materials. Adv. Mater. 2002, 14, 869-877. [CrossRef]

48. Kamali, M.; Ghahremaninezhad, A. A Study of Calcium-Silicate-Hydrate/Polymer Nanocomposites Fabricated Using the Layer-By-Layer Method. Materials 2018, 11, 527. [CrossRef]

49. Lee, S.H.; Kim, H.J.; Sakai, E.; Daimon, M. Effect of particle size distribution of fly ash-cement system on the fluidity of cement pastes. Cement Concr. Res. 2003, 33, 763-768. [CrossRef]

50. Konopacka-Łyskawa, D.; Kościelska, B.; Karczewski, J.; Gołąbiewska, A. The influence of ammonia and selected amines on the characteristics of calcium carbonate precipitated from calcium chloride solutions via carbonation. Mater. Chem. Phys. 2017, 193, 13-18. [CrossRef]

(C) 2019 by the authors. Licensee MDPI, Basel, Switzerland. This article is an open access article distributed under the terms and conditions of the Creative Commons Attribution (CC BY) license (http://creativecommons.org/licenses/by/4.0/). 